\title{
Jernej Weiss
}

\section{In Celebration}

Just as Slovene musicology occupies a prestigious place among other leading Slovene scientific disciplines, so the Musicological Annual holds a similar position among academic publications. On this occasion, let me point out some of the most important achievements that helped to establish the Annual's prominent position.

In the 50 years of its existence, some of the most important domestic and foreign scholars of musicology and ethnomusicology wrote for the Musicological Annual. In the 5 decades, as many as 61 issues were published, containing 631 articles, 63 summaries of MA degrees, PhDs and habilitation theses as well as 7 other texts. 294 authors from 29 countries in 7 languages contributed to the journal.

The firm basis that was formed by the previous editors-in-chief and the editors of special issues enabled the Musicological Annual to become internationally recognized and part of key citation databases. Even more important is the fact that with its two issues per year (mixed or thematic) the Annual maintains a tradition of continuous publishing, disseminates knowledge of state-of-the-art scholarly findings and through this fortifies its key role around the core of musicological and ethnomusicological scholarly efforts.

The striving for scholarly excellence has been the main constant of all previous editors-in-chief: professor emeritus Dr. Andrej Rijavec, professor Dr. Matjaž Barbo and of course the founder and longtime editor of the Annual, Slovene Academy member, professor emeritus Dr. Dragotin Cvetko. Each of them worked untiringly for the $A n$ nual and tried to the best of their abilities to promote the journal's good reputation in Slovenia and abroad.

The Musicological Annual has presented topics that were discussed by contemporary musicology and invited the most important domestic and foreign researchers to contribute to the journal's relevance. What is more, the Annual has furthered the musicological discourse in Slovene and clarified or even established domestic terminology that can only be achieved with regular and extensive use of the field's distinctive language. In future this will remain, along with furthering the journal's international reputation, one of the main objectives of the Musicological Annual: the constant search of harmony between the musicological world and the domestic scholarly achievements through the deepening of scholarly insights on the one hand and the constant enrichment of the Slovene musicology vocabulary on the other. The tasks ahead are endless but worth the effort, difficult but nevertheless attainable and without a doubt necessary for a healthy development of a national scholarly discipline. 
At the end of this prelude to the complex matter that follows may I, as editor, sincerely thank all our past contributors and express special gratitude to the authors of the contributions to the two special anniversary issues, the Editorial Board, the Assistant Editor, the International Advisory Board, the translators, the proofreaders and of course all the previous editors and other collaborators of the Annual for their relentless work. To all the domestic and foreign subscribers as well as to all other readers of the Musicological Annual goes a promise that the makers of the journal will continue to do all they can to achieve scholarly excellence and international recognition of the oldest Slovene scholarly publication devoted to musicology. 